\title{
Uma chave para a África
}

\author{
A key to Africa
}

\author{
Sílvio Marcus de Souza Correa \\ Professor, Programa de Pós-graduação em História/Universidade Federal de Santa Catarina. \\ silvio.correa@ufsc.br
}

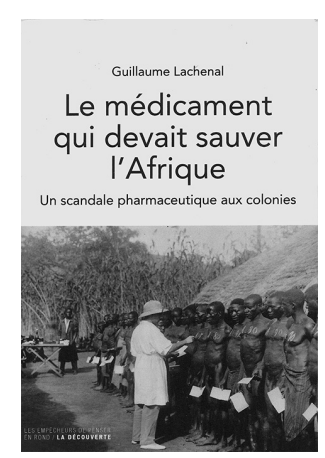
Le médicament qui devait sauver I'Afrique: un scandale pharmaceutique aux colonies. Paris: La Découverte. 2014. 283p.
LACHENAL, Guillaume.

$\mathrm{D}$ esde o início do século XX, a chamada doença do sono era um grande desafio à medicina tropical. ${ }^{1}$ Durante a Partilha da África, a doença tomou proporções alarmantes. Na década de 1920, a Alemanha já tinha perdido as suas colônias no continente africano, quando a imprensa deu notícias sobre uma nova wonder drug, considerada a "chave para África" (A key..., 1 set. 1922). O Bayer 205 foi tido como um medicamento promissor no combate à tripanossomíase africana. Estariam os alemães aptos a reaver suas colônias? (Das deutsche..., 22 set. 1922).

A Segunda Guerra Mundial poria fim a qualquer projeto colonial do Terceiro Reich. Quanto ao Bayer 205, sua eficácia foi superada por outro medicamento da indústria farmacêutica: a Lomidina ${ }^{\circledR}$. A história da Lomidina corresponde a uma fase pouco conhecida, mas capital, da luta colonial contra a doença do sono. Sobre ela, tem-se, agora, o livro de Guillaume Lachenal, mestre de conferências junto ao departamento de história e filosofia das ciências na Universidade Paris-Diderot.

O "medicamento que deveria salvar a África" suscitou uma série de dúvidas e incertezas quanto à sua eficácia, à sua posologia etc. Apesar disso, o medicamento foi usado na quimioprofilaxia contra uma doença tropical que debilitava a saúde dos trabalhadores. ${ }^{2}$ $\mathrm{Na}$ África portuguesa, as campanhas de vacinação se intensificaram até os últimos anos do colonialismo. ${ }^{3}$ Em Angola, algumas sociedades de capital privado tinham o seu próprio serviço de saúde. Na Companhia de Diamantes de Angola (Diamang), por exemplo, havia uma sessão autônoma chamada Missões de Profilaxia Contra a Doença do Sono (Varanda, 2014).

Mas, durante a euforia da utopia higienista colonial, houve uma hecatombe em Yokadouma, um vilarejo na parte oriental dos Camarões, então sob domínio colonial francês. Em meados de novembro de 1954, dezenas de pessoas morreram depois de terem sido vacinadas por uma equipe do serviço de higiene e de profilaxia responsável pela aplicação da Lomidina. $\mathrm{O}$ acidente de Yokadouma se inscreve numa história da medicina tropical que revela o lado 
falível, presunçoso e geralmente encoberto pela grandiloquência do discurso colonial. Para tratar disso, o autor evoca o valor heurístico da noção de "besteira colonial". Para Lachenal, a besteira não remete a uma deficiência da razão, mas a uma possibilidade intrínseca à razão. Pela confiança desmesurada nos procedimentos científicos, a razão pode tornar-se uma obstinação. A besteira não raro se confunde com arrogância. Por isso, ela se caracteriza pelo excesso e não pela falta de razão. A obstinação em erradicar a doença do sono e os métodos empregados como as campanhas de lodiminização preventiva fazem parte daquilo que o autor chamou de "besteira colonial".

No entanto, diante da morte de dezenas de pessoas e dos graves ferimentos de centenas de outras, além dos traumas, humilhações e coerções a que foram submetidos milhares de indivíduos durante as campanhas periódicas de lomidinização, a "besteira" pode vir a significar muito pouco e não passar de mero eufemismo.

Embora a análise do autor tenha ficado circunscrita aos (ab)usos da Lomidina, cabe informar que outras "besteiras" como o desmatamento e mesmo a matança de animais selvagens foram práticas largamente adotadas nas campanhas de controle ou erradicação da tripanossomíase africana (Correa, 2014).

O "império da besteira" não se restringiu às fronteiras africanas. Enquanto Aníbal Bettencourt, Aldo Castellani, David Bruce, Robert Koch e outros buscavam decifrar a doença do sono, outras enfermidades preocupavam as autoridades sanitárias e de higiene nos trópicos. Suas técnicas e métodos no combate a certas epidemias não foram diferentes. Uma campanha de vacinação obrigatória contra a varíola levou a uma revolta no Rio de Janeiro em 1904 (Chalhoub, 1996). No Brasil meridional, campanhas sanitárias para erradicação da malária tiveram por alvo algumas bromeliáceas, reservatórios naturais à proliferação dos mosquitos anofelinos (Oliveira, 2011). Ou seja, a presunção ou arrogância de uma razão médica, o autoritarismo e a violência de certas medidas de higiene, sanitárias ou profiláticas não foram apanágios do colonialismo em África. Dito de outro modo, a "besteira colonial" teve suas similares em contextos pós-coloniais.

Ao tratar de um medicamento considerado "a chave para África", Guillaume Lachenal brinda com uma abordagem inovadora, em termos teóricos e metodológicos, a historiografia da medicina tropical.

\section{NOTAS}

\footnotetext{
${ }^{1}$ Angola, por exemplo, acolheu uma das primeiras expedições científicas para o estudo da doença do sono (Bettencourt, 1903).

${ }^{2}$ Para ficar num exemplo, ao elogiar a assistência médico-cirúrgica do serviço de saúde da Diamang, o doutor Fernando Correia afirmou que a referida sociedade mineradora acabava também "por lucrar economicamente, visto que a economia de saúde e de vidas se repercute sempre, mais cedo ou mais tarde, direta ou indiretamente, sobre a produção" (citado em Picoto, 1953, p.2703).

${ }^{3}$ Em 1963, pelo decreto n.45.177, foi criada a Missão de Combate às Tripanossomíases (MCT) que, no ano seguinte, entrou em ação. O escopo da nova organização era "a luta total, em todos os campos, contra as tripanossomíases consideradas nos múltiplos aspectos-médico, veterinário, entomológico, agronômico, etc." (Vinte anos de luta..., 1966, p.17). Entre outras atividades da MCT, a campanha de pentamidinização em Angola foi reconhecida do outro lado do Atlântico. Em 20 de agosto de 1970, em sessão realizada na Academia Nacional de Medicina, no Rio de Janeiro, o médico brasileiro Olympio da Fonseca Filho fez elogios à obra de Portugal no combate à doença do sono.
} 


\section{REFERÊNCIAS}

A KEY...

A key to Africa. Rhodesia Herald. 1 set. 1922.

BETTENCOURT, Aníbal.

La maladie du sommeil: rapport présenté au Ministère de la Marine et des Colonies par la Mission envoyée en Afrique Occidentale Portugaise. Lisboa: Libanio da Silva. 1903.

CHALHOUB, Sidney.

Cidade febril: cortiços e epidemias na Corte imperial. São Paulo: Companhia das Letras. 1996.

CORREA, Silvio M. de Souza.

Evicção da fauna bravia: medida radical de saneamento na África colonial. Revista de Ciências Humanas, v.14, n.2, p.410-422. 2014.

DAS DEUTSCHE....

Das deutsche Schlafkrankheitsmittel: der Schlüssel zu Afrika in deutscher Hand. Lüderitztbuchter Zeitung. 22 set. 1922.
OLIVEIRA, Eveli S. D'Ávila.

O combate à malária em Florianópolis e suas implicações ambientais. Tempos Históricos, v.15, p.405-429. 2011.

PICOTO, José.

Assistência médico-cirúrgica na Luanda pelo serviço de saúde da Diamang. Anais do Instituto de Medicina Tropical, v.10, n.4. (separata). 1953.

VARANDA, Jorge.

Cuidados biomédicos de saúde em Angola e na Companhia de Diamantes de Angola, c. 19101970. História, Ciências, Saúde-Manguinhos, v.21, n.2, p.587-608. 2014.

VINTE ANOS DE LUTA...

Vinte anos de luta contra a doença do sono, 1946-1965. O Médico, n.792, p.17. (separata). 1966.

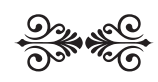

